\title{
現場だより
}

\section{株式会社 富士通研究所}

\section{1. まえがき}

株式会社富士通研究所は, 富士通グループの研究開 発を担当する機関として, 富士通の全額出資により設 立された独立した研究所で, 創造と高信頼という理念 を揭げ, 自主技術開発を強力に押し進める富士通の幅 広い研究開発要求に応じている。ここに所属する $2 つ$ の研究のうち川崎研究所は, 富士通の発祥以来技術の 中心であった川崎市中原区にある富士通川崎工場と隣 接し, 主として通信・情報処理システムの研究開発を 担当している. 厚木研究所は, 厚木市の研究地区であ る森の里に位置し, 主として部品・材料の研究学園開 発を担当している.

\section{2. 生い立 ち}

富士通研究所は, 重複投資を排し, 研究技術者が業 務に専念できる雾囲気を作るという目的で，それまで 各技術部門に分かれていた研究部隊を統合し, 昭和 37 年 5 月, 富士通の内部組織として発足した. 昭和 39 年 10 月には, 研究所棟の第 1 期工事が完成して, 分散していたかなりの部門を 1 䇢所に結集することが できた。

昭和 43 年 11 月, 当研究所は株式会社として分離独 立した。これは, 技術革新の時代に対処して技術尊重 の姿勢をより明確に打ち出し, 研究者の身分の安定を はかり, 開発成果の適性な評価を行うことを眼目とし て行われたものである.

昭和 48 年には, 研究所 2 号館が川崎工場の隣接地 に完成した.これが, 現在研究所の本社機構と川崎研 究所が入っている建物である（写真 $\mathbf{1}$ ).

昭和 58 年, 部品・材料の強化をはかるべく, 厚木市 に厚木研究所 (写真 2) を新設して, 川崎地区の担当部 門と，それまで神戸・明石地区にあった研究部隊とを 移して陣容を整え, 川崎研究所・厚木研究所の 2 研究

$\dagger$ 株式会社 富士通研究所

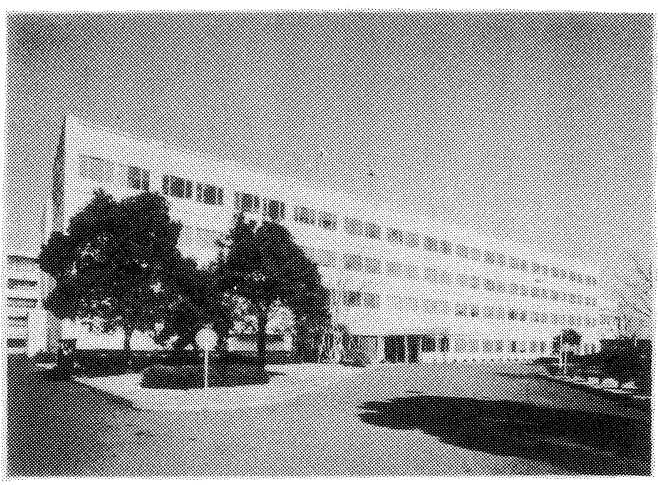

写真 1 川崎研究所

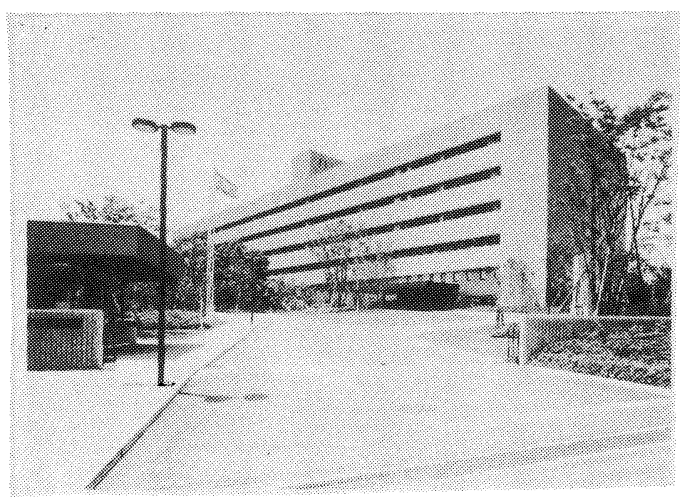

写真 2 厚木研究所

所態勢とした。

\section{3. 研究所の組織と運営}

(株)富士通研究所の組織を図 1 に示す。運営費用は 一部関係会社からの委託研究費があるが，ほとんど全 額富士通の負担である. 社員の採用者の中から適任者 を出向させる形で全員が構成されている.したがって 労働条件も労働組合も一緒で, 研究が完成して技術移 管に伴って研究者の一部が富士通に移るときも何ら問 題は起きていない. 


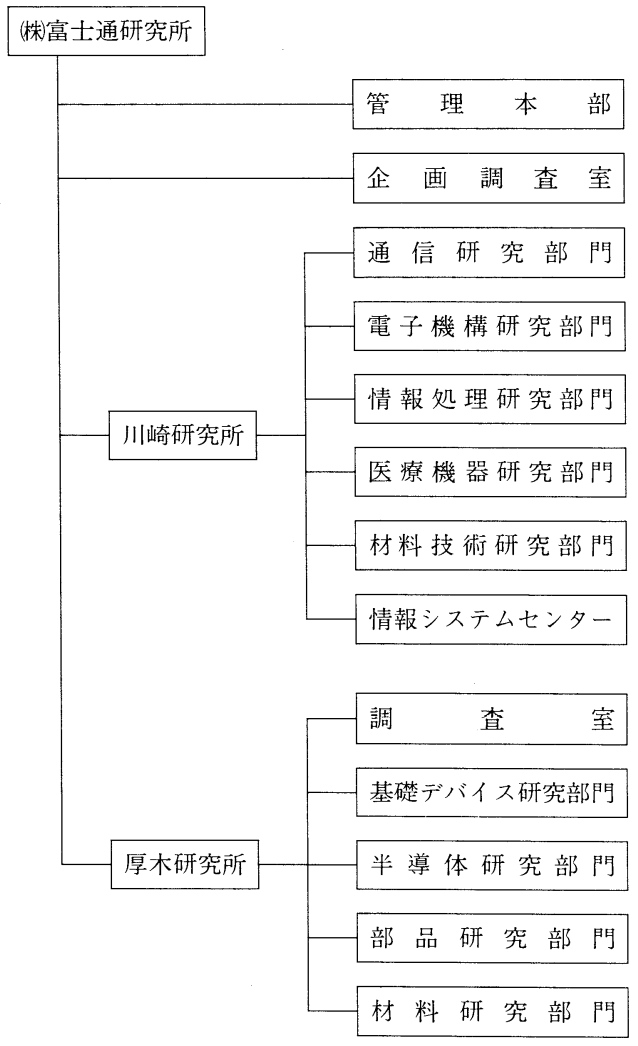

図 1 (株富士通研究所組織図

\section{4. 主な研究分野}

\section{1 通信分野}

衛星通信, 無線通信, 光通信に関する伝送・交換方 式と機器の研究開発. ISDN/ISN 関連ディジタル通 信網，OA 網などのディジタル網と通信処理システム の研究開発，それらの通信端末に関する方式および機 器の研究開発を行っている.

この分野で最近得られた研究成果のうち, 当学会に 関係の深いものとしては, マルチフィールド駒落とし 画像帯域圧縮, GaAs FET 高周波大電力送信機, HEMT (High Electron Mobility Transistor) および GaAs FET による低雑音増幅器がある。

\section{2 情報処理分野}

視覚・触覚を持った知能ロボット，文字・図形・音 声等のパターン認識, 自然言語処理, データベース抒 よび知識ベース，新しいコンピューターアーキテクチ
ャー, 画像処理, $\mathrm{CAD}$, 大容量磁気記録, 光ディス ク, プリンター, ファクシミリなどの広い範囲にわた る研究開発を行っている. 当学会に関連の深い成果と しては, 並列処理機能とリアルタイムビデオ入出力機 能を持つセルアレイ画像プロセッサー, A 4 判原稿を RGB 3 色分解によって読み取るカラー高忠実度画像 入力機構がある.

\section{3 医療機器分野}

超音波診断装置, 高周波ドップラー血流計などの研 究開発を行っている.

\section{4 半導体分野}

Si-LSI 技術, GaAs-IC, HEMT, 電子ビーム技術 を中心にした微細加工技術, 半導体結晶技術およびそ の評価技術, MBE やイオンプロセス等の新しいプロ セス技術, 発光素子, 受光素子, 光集積回路, 赤外線 デバイスとその材料等の研究開発を行っている.

関連の成果としては, 前述の高周波大電力送信機や 低雑音増幅器に使用した GaAs FET, HEMT があ る。

\section{5 部品材料分野}

高密度バブルメモリー, アモルファスシリコン等の 薄膜応用デバイス, 液晶, EL, ECD 等の平面形ディ スプレイ、レーザー応用計測，ホログラムスキャナー 等のホログラム応用デバイスおよびシステム, 各種セ ンサー, 金属材料, 低温材料, セラミック, 電子線レ ジストや LSI 等の素子間分離耐熱樹脂, 液晶用材料, 印刷・記録用材料，材料の分析と処理・加工技術など の研究開発を行っている. 関連の成果としては, 大容 量アモルファスシリコン薄膜トランジス夕駆動 LCD パネルや $\mathrm{EL}$ パネルがある.

\section{5. ま と め}

技術革新の激しい通信・情報，エレクトロニクスの 産業分野にあって, 企業の繁栄を維持し, 推し進める には，技術開発において一歩先んずることが必要であ る、そこで，夕イミングを失することなく，新しい分 野に挑戦し，優れた，役に立つ技術を開発すること が，当社に与えられた使命である。研究者は，「とも かくやってみろ」という声に応えて，未知の領域の興 味に引かれ, 緑に囲まれた惠まれた環境で日久研究に いそしんでいる。 